\title{
UNIVERSITY STAFF ADOPTION OF IPADS: AN EMPIRICAL STUDY USING AN EXTENDED TECHNOLOGY ACCEPTANCE MODEL
}

\author{
Michael Lane \\ University of Southern Queensland \\ Michael.Lane@usq.edu.au \\ Adrian Stagg \\ University of Southern Queensland \\ Adrian.Stagg@usq.edu.au
}

\begin{abstract}
The adoption of iPads in the university sector has been widespread, with attention predominantly being directed to students' adoption and use of iPads. However, there is a lack of empirical research which has critically examined the key factors influencing university staff adoption of iPads. The main objective of this research is to empirically examine key factors influencing adoption of iPads by university staff. An online survey was used to collect quantitative data to validate the measurement model and test hypothesised relationships in an extended TAM. The findings from the results of the data analyses show that university staff consider iPads to be easy to use and useful, with a high level of compatibility with their work. Social status had no influence on the attitude of university staff to using an iPad in their workplace. However, older university staff and/or university staff with no previous experience in using a similar technology such as an iPhone or smartphone found iPads less easy to use. Furthermore, a lack of formal university ICT support for end-users impacted negatively on the use of iPads by university staff. This research contributes to theory by validating and establishing support for an extended TAM which is contextualized for iPad adoption by university staff. This model has practical application because it is generalisable for a range of mobile computing devices and can be used to evaluate the adoption and use of mobile computing devices in a range of industries beyond the university sector.
\end{abstract}

Keywords: Technology acceptance model, iPad, social status, age, previous experience with similar technology, ICT support

\section{INTRODUCTION}

Mobile computing and e-learning continues to drive the focus of higher education course design and delivery (Caudill 2007; Murphy et al. 2013). Hence, there is an increasing need for university staff to adopt mobile devices such as iPads for experimentation, professional development and implementation within their work practices, including administration, research and teaching. Thus, the current paradigm shift in both technology and mobile computing challenges higher education providers to effectively leverage the multi-functionality of mobile devices such as smart phones and iPads (Murphy et al. 2013; Wiebrands 2012). These mobile devices have the potential to extend educational experiences through touch, location-aware learning, embedded multimedia, and multiple channels of educational content delivery. Support for university academic and professional staff to conduct their work more effectively by using mobile devices such as smart phones and tablets in their work will be critical. The factors leading to mainstream mobile device adoption in the university workplace is an important consideration for those in senior management roles responsible for developing, supporting and evaluating these activities. 
This paper is structured as follows. Firstly, a review of the relevant literature is conducted in relation to iPads and their adoption in higher education and the technology acceptance model (TAM) to provide the theoretical and conceptual basis for our proposed model of iPad adoption by university staff. Next, the hypothesised relationships in the proposed university staff iPad adoption model are discussed and justified in relation to the relevant literature. Then the research methodology used in this research is described and justified. The results of the data analysis results are discussed in terms of the survey population and response rate, demographics of survey respondents and the reliability and validity of the measurement model. The next section discusses the results of the hypothesis testing in relation to the existing literature. Finally, we present our conclusions and implications for theory and practice in relation to the use of iPads by university (academic and professional) staff in higher education.

\section{BACKGROUND AND MOTIVATION FOR THIS STUDY}

The use of iPads by university staff has increased steadily in response to the release of the iPad in 2010, with conservative estimates putting total sales of iPads based on Apple's quarterly financial report for October 2013 at 170 million worldwide (Costello 2014). Consistent anecdotal evidence suggests there is a need for university staff to be appropriately supported so that they can effectively make the transition to integrating these mobile devices into their daily work activities. Some studies regarding the practical implications and impact of the iPad have been undertaken in the university sector; however, these studies have primarily focused on students (Hoover \& Valencia 2011; Pepperdine University 2012; Wu, Kuo \& Wu 2013). Hence, there is a lack of empirical research which has critically assessed the factors determining the adoption of iPads by university staff. This research project seeks to understand, within the university environment, the factors leading to widespread adoption and the perceived usefulness of these devices by university staff in their work. The Technology Acceptance Model (TAM) provided the theoretical foundation for this research and the proposed model of University Staff Adoption of iPads. The main research question investigated in this project was: To what extent do factors such as work compatibility, previous experience in using a similar technology such as an iPhone or smartphone, age and social status influence university staff adoption of iPads in their work?

\section{PREVIOUS LITERATURE REGARDING IPAD/TABLET USE IN HIGHER EDUCATION}

The iPad achieved a fifty-seven percent share of the Tablet PC market in the fourth quarter, 2011 (Ong 2011). This trend, coupled with the 2012 launch of iBooks and the iTunes U app, show Apple Corporation attempting to align itself with the education sector. Universities such as Stanford, University of California and University of Central Florida (Shurtz, Halling \& McKay 2011), and Australian counterparts such as the University of Adelaide (Cross 2010) and University of New England and, more recently, the University of Western Sydney, have taken a proactive stance by issuing iPads to commencing students. Research into the acceptance and use of iPads in higher education has focused on ubiquitous and flexible learning (Kukulska-Hume 2012; Maddux \& Johnson 2010). Hence, iPads are viewed primarily as a presentation tool, and an e-text and e-learning content delivery mobile device (Becker 2011; Shen 2010)—which is limiting their potential for adding value to both the roles and activities of university staff and students.

\section{Previous empirical research on the use of iPads by university staff}

Two main studies were identified as directly relevant to this project as they focused on the adoption and continuing developmental needs of iPads by academic staff in higher education. Oldfield and Cochrane (2011) worked with twenty staff in a Business and Law Faculty to map key staff development issues in relation to the adoption and use of iPads. They found two dimensions requiring support, namely, an initial 'learning curve' (primarily self-directed learning)—which matured to a second 
communal learning phase (facilitated by a Community of Practice model). Qualitative data was gathered via surveys and focus groups.

Kelly and Schrape (2010) also undertook a primarily qualitative study of staff acceptance and use of iPads in teaching by segregating the staff learning curve into three, one-month blocks (familiarisation, integration and reflection). The focus of data collection was iPad usage in daily activities and the compatibility of the iPad with the learning management system (LMS), as well as a list of the most used apps. The lack of empirical research that has been undertaken into the use of iPads by university staff provided the motivation for the development and testing of a university staff iPad adoption model.

\section{TECHNOLOGY ACCEPTANCE MODEL AS A THEORETICAL FRAMEWORK FOR IPAD ADOPTION}

The TAM, developed by Davis (1989), seeks to understand the rationale for technology adoption among users. As a predictive model of technology adoption it is considered to be mature and has been extended to accommodate a wide range of technologies including eBook readers (Read, Robertson \& McQuilken 2011), online learning communities (Liu et al. 2010), mobile payment systems (Lee, Kozar \& Larsen 2003), mobile learning paradigms (Park, Nam \& Cha 2011) and tablet PCs (Moran, Hawkes \& El Gayar 2010). The latter was of particular interest to this project, given there are some similarities between tablet PCs and iPads.

The original TAM (Davis 1989) used predictive factors based upon users' perceptions of ease of use and usefulness (Nair \& Das 2011). However, the model has been extended by numerous researchers (notably to include intent to use) (Davis, Bagozzi \& Warshwa 1989). This has been imperative given the ubiquitous nature of the internet which has led to wide scale adoption of many different internet enabled technologies and the need for validated research concerning the adoption and use of internet enabled technologies.

Mathieson (1991) argued that the base TAM over-simplified the adoption process, but variants of extended TAM have been developed to accommodate variables such as mobile learning attitude (Park 2009), and context for use (McFarland \& Hamilton 2006). This research uses an extended TAM to contextualize the assessment of adoption and use of iPads by university staff, as most of the previous literature only investigated student acceptance and uptake of iPads. Hence, the technology acceptance model adapted for this research uses some specific and relevant external variables for the context of this study which have been shown to moderate the relationships in TAM (Gerpott, Thomas \& Weichert 2013; Lee, Kozar \& Larsen 2003; Straub, Keil \& Brenner 1997). This research seeks to examine whether compatibility with university staff work, previous use of a device with a similar interface and operating system (in this case an iPhone or android or Windows smart phone), age and the level of ICT end user support affects university staff adoption and use of iPads.

The relatively new nature of the iPad as a touch screen and internet enabled mobile computing device and its recent adoption in higher education provides the justification for an extended variant of TAM as an appropriate theoretical framework for evaluating the adoption and use of iPad/tablets by university staff (Knight \& Burn 2011).

\section{HYPOTHESISED RELATIONSHIPS IN THE PROPOSED RESEARCH MODEL}

Compatibility is defined as the degree to which a technological innovation such as iPad is perceived as being consistent with existing values, needs, and past experiences of potential adopters (i.e. university staff in this study) (Moore \& Benbasat 1991). Compatibility has been found to be strongly associated with the successful adoption and use of technological innovations (Guiltinan 1999; Holak \& Lehmann 1990; Taylor \& Todd 1995; Tornatzky \& Klein 1982). Kotler (2003) states that compatibility refers to the degree of fit of an innovation with an individual in a social system (university work in this research) 
and observed that compatibility can influence the adoption of innovative products such as personal computers. A number of previous empirical studies have found that compatibility is a key factor that influences the perceived ease of use (Lai \& Chang 2011) and perceived usefulness (Lai \& Chang 2011) of technological innovations. Lai and Chang (2011) found that compatibility directly impacts on the perceived ease of use and perceived useful of a technological innovation.

Therefore, the literature provides support for the following two hypotheses:

H1: Compatibility of an iPad with staff work is positively associated with the perceived usefulness of an iPad.

H2: Compatibility of an iPad with staff work is positively associated with the perceived ease of use of an iPad.

Social status is defined as the degree to which use of a technological innovation such as an iPad is perceived to enhance one's image or status in one's social system (Moore \& Benbasat 1991). It is reasonable to assume that if adopting a new technology is considered to enhance one's social image, the attitude toward adopting the new technology will be positive (Choi et al. 2003; Karahanna, Straub \& Chervany 1999). Therefore, if a user perceives that adopting a new technology such as an iPad will showcase their good image or social status in an organisation, then the user will have a positive attitude towards an iPad. Therefore, we propose the following hypothesis:

H3: The social status of using an iPad in the workplace has a positive association with the attitude to using an iPad.

Perceived usefulness is defined as the extent to which a person perceives that using a new technology such as an iPad will enhance one's job performance (Chong et al. 2010). Previous studies have found that perceived usefulness has a significant impact on the adoption of a technology, including the attitude towards a technology and the intention to use a technology (Chong et al. 2010; Lee, Cheung \& Chen 2005). If university staff perceive an iPad will be useful in their work they are more likely to have a positive attitude and intention toward using an iPad. Hence, the following hypotheses have been proposed:

H4: Perceived usefulness of an iPad has a positive association with the intention to use an iPad.

H5: Perceived usefulness of an iPad has a positive association with the attitude towards using an iPad.

Perceived ease of use is defined as the extent to which a person believes using a technology would be relatively effortless (Davis 1989). A number of previous studies have found perceived ease of use is a key determinant of attitude towards using a new technology and the actual use of a new technology (Davis 1989; Lapczynski \& Calloway 2006; Lu \& Viehland 2008; Malhotra \& Galleta 1999). If university staff perceive an iPad to be easy to use it is likely to influence their attitude towards using an iPad and their actual use of an iPad. Therefore, the following hypotheses are proposed:

H6: Perceived ease of use of an iPad has a positive association with the attitude towards using an iPad.

H7: Perceived ease of use of an iPad has a positive association with the frequency of actual use of an iPad.

Attitude to using a technological innovation has long been established by previous studies of technology adoption to influence intention to use which, in turn, influences actual use of a technological innovation (Davis 1989; Davis, Bagozzi \& Warshwa 1989; Horan et al. 2004; Karahanna, Straub \& Chervany 1999; Lu \& Viehland 2008; Straub, Keil \& Brenner 1997). Previous studies suggest that university staff's' attitude and subsequent intent to use a new technology such as an iPad ultimately determines their adoption and actual use in a workplace. Therefore, the following hypotheses are proposed: 
H8: Attitude towards using an iPad has a positive association with the intention to use an iPad.

H9: Intention to use an iPad has a positive association with the frequency of actual use of an iPad.

It has been found that those who are early adopters of new technologies in the workplace, such as the higher education sector, expected their ICT support staff to continuously develop their knowledge, to understand user expectations and to maintain a high level of communication between support staff and users (Kagaari, Munene \& Ntayi 2010). A number of previous studies have established that computing support is positively associated with the adoption of a new technology in the workplace (Igbaria et al. 2007; Schaper \& Pervan 2007; Thompson, Higgins \& Howell 1991). Hence, the existing literature suggests that an appropriate level of computing support provided at the organization level for the use of iPads by university staff will have a positive impact on the frequency of actual use. Therefore, we propose the following hypothesis:

H10: ICT support has a positive association with the frequency of actual use of an iPad.

The adoption of new computing devices has been positively linked to prior experience and use of existing similar platforms and/or similar devices (Jackson, Chow \& Leitch 1997; Shih \& Venkatesh 2004). Past experience with similar technologies is likely to affect one's perceptions about the ease of use of a new technology such as an iPad (Tan et al. 2012). The iPhone, android and Windows smartphones share similar or identical user interfaces and operating systems to an iPad. Hence, it is argued that familiarity with aspects of a similar technology will be positively associated with the users' perceptions of ease of adoption of the technology. Therefore, we propose the following hypothesis:

H11: Users with previous experience in using a similar technology such as an iPhone or smartphone will rate the perceived ease of use of an iPad higher than users with no previous experience of using a similar technology such as an iPhone or smartphone.

Prior studies have examined the interaction between age and technology adoption (Goldin \& Katz 2008; Reisdorf 2011). Empirical research into the adoption of mobile learning devices has indicated little significant difference in perceived usefulness and perceived ease of use due to individual characteristics such as gender or age (Tan et al. 2012). However, age has been found to be indicative of risk-avoidance and conservativeness, and negatively associated with adoption of a new technological innovation (Wang, Dou \& Zhou 2008). Therefore, we propose the following hypothesis:

H12: Age is negatively associated with the perceived ease of use of an iPad.

The proposed research model in Figure 1 depicts the hypothesized relationships tested in this study. 


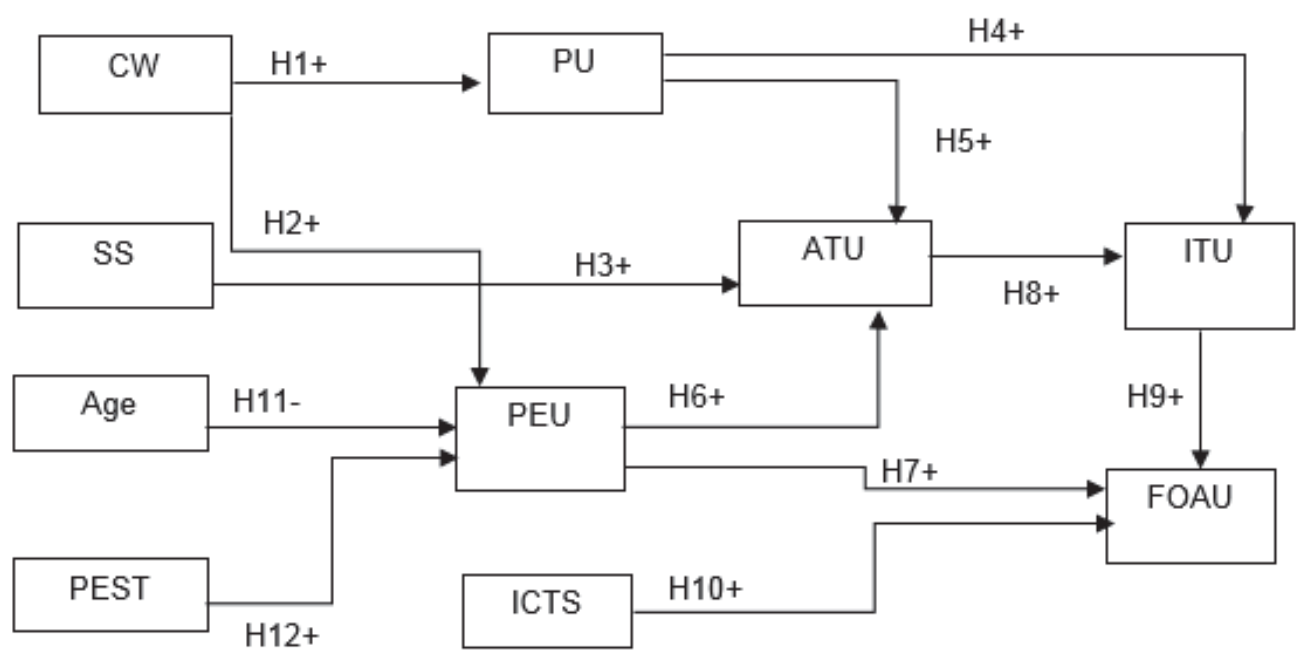

\footnotetext{
Legend $C W=$ Compatibility with work; $S S=$ Social status; $P E U=$ perceived ease of use; $P U=$ perceived usefulness; $A T U=$ Attitude to use; $I N T U=$ Intention to use; FOAU = Frequency of actual use; Age; PEST = Previous experience with similar technology; ICTS = ICT Support;
}

Figure 1 Research Model - University staff adoption of iPads (Source: this research)

\section{RESEARCH METHODOLOGY}

This research was guided by a positivist research design. We used a cross-sectional survey method to collect primarily quantitative data to test the hypothesised relationships in the proposed research model (Figure 1). The survey was administered online after ethics clearance was obtained from the University Ethics Committee. Respondents were assured that their responses were anonymous. The survey instrument was developed using existing validated survey instrument items which were adopted/adapted from a number of previous empirical studies (see Table 1) (Straub, Boudreau \& Gefen 2004). Face validity of the survey instrument was verified and refined through a pretest of the survey instrument with five university staff with substantial experience in survey research. 


\begin{tabular}{|c|c|c|}
\hline Construct & No of items (scale) & $\begin{array}{l}\text { Adopted/adapted from previous } \\
\text { empirical studies }\end{array}$ \\
\hline $\begin{array}{l}\text { Compatability with } \\
\text { work }(\mathrm{CW})\end{array}$ & 3 items 7 point Likert-type & $\begin{array}{l}\text { Compatibility (Moore \& Benbasat 1991, } \\
\text { p. 216) }\end{array}$ \\
\hline ICT Support (ICTS) & 3 items 7 point Likert-type & $\begin{array}{l}\text { Facilitating Conditions (Thompson, } \\
\text { Higgins \& Howell 1991, p. 132) }\end{array}$ \\
\hline Social Status (SS) & 3 items 7 point Likert-type & $\begin{array}{l}\text { Image / Social Status (Moore \& Benbasat } \\
\text { 1991, p. 216) }\end{array}$ \\
\hline $\begin{array}{l}\text { Perceived Usefulness } \\
\text { (PU) }\end{array}$ & 5 items 7 point Likert-type & $\begin{array}{l}\text { Perceived Usefulness (Davis 1989, p. } \\
\text { 331) }\end{array}$ \\
\hline $\begin{array}{l}\text { Perceived Ease of } \\
\text { Use (PEU) }\end{array}$ & 6 items 7 point Likert-type & $\begin{array}{l}\text { Perceived Ease of Use (Davis 1989, p. } \\
\text { 331) }\end{array}$ \\
\hline $\begin{array}{l}\text { Attitude to Use } \\
\text { (ATU) }\end{array}$ & 3 items 7 point Likert-type & $\begin{array}{l}\text { Attitude (Ajzen \& Fishbein 1980) (Taylor } \\
\& \text { Todd 1995, p. 173) }\end{array}$ \\
\hline $\begin{array}{l}\text { Intention to Use } \\
\text { (ITU) }\end{array}$ & 3 items 7 point Likert-type & $\begin{array}{l}\text { Intention to use (Ajzen \& Fishbein 1980) } \\
\text { (Taylor \& Todd 1995, p. 174) }\end{array}$ \\
\hline $\begin{array}{l}\text { Frequency of Actual } \\
\text { Use (FOAU) }\end{array}$ & 1 items 7 point Likert-type & $\begin{array}{l}\text { Single item rating of frequency of use per } \\
\text { week }\end{array}$ \\
\hline Age & 1 item Ordinal-type & Single item ordinal scale of age categories \\
\hline $\begin{array}{l}\text { Previous Experience } \\
\text { with a Similar } \\
\text { Technology (PEST) }\end{array}$ & 1 item Nominal-type & $\begin{array}{l}\text { Single item nominal variable for previous } \\
\text { experience with similar technology } \\
\text { converted to binary variable for analysis }\end{array}$ \\
\hline
\end{tabular}

Table 1 Sources of survey questionnaire items measuring each construct

\section{RESULTS OF DATA ANALYSIS}

\section{Study population and survey response rate}

The University employed approximately 1300 staff (including academic and professional positions)at the time when this research was conducted. Four hundred iPads are estimated to be used by university staff at the time the survey was conducted according to the Division of ICT Services. This number was estimated from the number of iPads purchased for university staff and iPad campus network usage statistics provided by University ICT Services. The survey received 87 usable responses from university staff using iPads in their work (an estimated 22 percent response rate within the identified iPad university staff user population of 400). The survey focused on the use of iPads in activities relating to learning, teaching and general duties directly pertaining to university business. The survey respondents were relatively evenly spread across the academic (53.5 percent) and professional (46.5 percent) employee groups.

\section{Demographics of survey respondents}

University staff usage of iPads is dominated by the age categories 36 years and higher (Table 2). These age categories represented 85 percent of respondents, with the 18 to 35 age category accounting for the remaining 15 percent. More importantly, almost half of the university staff who responded to this survey are in the 46-55 and 55 and over age categories. The distribution of age categories in the survey responses is representative of the distribution of the age categories of university staff overall. Most, if not all, Australian universities have an ageing workforce. 


\begin{tabular}{rcc}
\hline Age Category & Frequency & Percentage \\
\hline $\mathbf{1 8 - 2 5}$ & 2 & 2.3 \\
$\mathbf{2 6 - 3 5}$ & 11 & 12.6 \\
$\mathbf{3 6 - 4 5}$ & 33 & 37.9 \\
$\mathbf{4 6 - 5 5}$ & 29 & 33.3 \\
Over 55 & 12 & 13.8 \\
Total & 87 & 100.0 \\
Missing & 1 & \\
\hline
\end{tabular}

Table 2 Distribution of survey responses by Age category

University staff roles were evenly distributed between academic staff ( 46.5 percent) and professional staff (53.5 percent) in the survey responses, as shown in Table 3.

\begin{tabular}{rcc}
\hline University Staff Role & Frequency & Percentage \\
\hline Academic staff & 40 & 46.5 \\
Professional staff & 46 & 53.5 \\
Total & 86 & 100 \\
Missing & 2 & \\
\hline
\end{tabular}

Table 3 University staff role (Academic or Professional)

\section{Measurement model for university staff adoption of iPads/tablets}

The testing of the proposed relationships between the seven constructs and three single item measures in the proposed University Staff Adoption of iPads model (see Figure 1) was conducted using Partial Least Squares (PLS) and the software package Smart PLS (Ringle, Wende \& Will 2005). The sample size of 87 valid responses from university staff using iPads was not large enough for covariance based SEM to be used. PLS is a second generation multivariate analysis technique for testing means based structural equation models (Wold 1985). PLS does not require a normal distribution, unlike covariance based SEM, and will work with relatively small data sets (Ghapanchi \& Aurum, 2012a, Ghapanchi \& Aurum, 2012b, Eikebrokk \& Olsen, 2007). As a rule of thumb, the minimum sample size for PLS analysis should be 10 times the number of items present in the most complex construct, or 10 times the largest number of independent variables impacting on a dependent variable. In the proposed research model, the most complex construct is perceived usefulness, which has 6 items; and the largest number of independent variables which are estimated to impact on a dependent variable (intention to use) is 3 (Chin 1998; Karahanna, Straub \& Chervany 1999). PLS simultaneously evaluates the measurement model and the theoretical model by assessing the reliability and validity of the theoretical constructs and relationships between those constructs (Barclay, Thompson \& Higgins 1995).

In this study the PLS model is analysed and interpreted in a rigorous two phase approach: (1) an assessment of the reliability and validity of the measurement model describing the relationship between the latent constructs and their manifest indicators; and (2) an assessment of a structural model describing the relationships between the latent constructs (Barclay, Thompson \& Higgins 1995). This approach ensures that construct measures are valid and reliable before drawing conclusions about the predictive strength of relationships between the constructs in the theoretical model.

\section{Assessment of the measurement model for university staff adoption of iPads}

The measurement model in PLS is assessed for construct validity and reliability and the extent to which the underlying manifest variables accurately reflect and measure their constructs (Hair et al. 2012; Straub, Boudreau \& Gefen 2004). An assessment of the measurement model evaluates construct 
validity and the extent to which the underlying manifest variables accurately reflect their constructs. This assessment includes the individual item reliability, construct reliability, average variance extracted (AVE) analysis, and convergent validity and discriminant validity (see Table 4 and Table 5) (Straub, Boudreau \& Gefen 2004).

Individual item reliability is considered adequate when an item has a factor loading greater than 0.7 on its intended construct, which implies more shared variance between the construct and its measures than error variance (Carmines \& Zeller 1979). The factor loadings for the 27 items measuring the 7 constructs in the research model were all above the recommended 0.7 (Chin 1998; Fornell \& Larcker 1981) (see Table 5). Construct reliability was measured using composite reliability, Cronbachs alpha and average variance extracted (AVE). Reliability and convergent validity was interpreted using 0.7 level, which has been widely suggested as the benchmark for moderate reliability (Nunnally 1979). In this research, all the constructs demonstrate high reliability and convergent validity with values for composite reliability and Cronbachs alpha—which are above the recommended 0.7 level. AVE measure quantifies the amount of variance that a construct captures from its measurement items (indicators) (Hair et al. 2012). All of the AVE measures for the latent variables exceed the recommended 0.5 value (Fornell \& Larcker 1981).

\begin{tabular}{crrrrr}
\hline & AVE & $\begin{array}{r}\text { Composite } \\
\text { Reliability }\end{array}$ & $\begin{array}{r}\text { Cronbachs } \\
\text { Alpha }\end{array}$ & Communality & Redundancy \\
\hline ICTS & 0.82 & 0.93 & 0.90 & 0.82 & 0.00 \\
PEU & 0.83 & 0.96 & 0.95 & 0.83 & 0.08 \\
PU & 0.86 & 0.97 & 0.97 & 0.86 & 0.55 \\
ATU & 0.84 & 0.95 & 0.94 & 0.84 & 0.26 \\
CW & 0.85 & 0.94 & 0.91 & 0.85 & 0.00 \\
ITU & 0.87 & 0.95 & 0.93 & 0.87 & 0.50 \\
SS & 0.85 & 0.94 & 0.92 & 0.85 & 0.00 \\
\hline
\end{tabular}

Legend CW = Compatibility with work; SS = Social status; PEU = perceived ease of use; PU = perceived usefulness; ATU = Attitude to use; INTU = Intention to use; FOAU = Frequency of actual use; Age; PEST = Previous experience with similar technology; ICTS = ICT Support

Table 4 Reliability of Constructs in Proposed Research Model (Source: this research)

To assess discriminant validity, AVE should be greater than the variance shared between the construct and other constructs in the model (squared correlation between two constructs) (Ghapanchi \& Aurum 2011; Hair et al. 2012; Henseler, Ringle \& Sinkovics 2009). Adequate discriminant validity is determined by comparing the square root of the AVE value of each construct and its correlation with the other constructs in the model. All of the constructs in the model have square root AVE values which are higher than their corresponding correlation values with the other constructs.

The items retained for each factor were determined from the factor loadings and cross loadings produced by PLS. All items were retained as all the factor loadings were above the recommended 0.7 level (see Table 5). Overall internal validity was established through ensuring that the constructs measuring dimensions of TAM for university staff iPad use had adequate face and content validity and adequate convergent and discriminant validity. Hence, the constructs measured in this study were found to be reliable and valid (see Tables 4 and 5) and can be replicated in further studies involving the adoption and use of mobile devices. 


\begin{tabular}{|c|c|c|c|c|c|c|c|}
\hline Construct items & ICTS & PEU & PU & ATU & $\mathrm{CW}$ & ITU & SS \\
\hline attitude1 & 0 & 0 & 0 & 0.89 & 0 & 0 & 0 \\
\hline attitude2 & 0 & 0 & 0 & 0.91 & 0 & 0 & 0 \\
\hline attitude3 & 0 & 0 & 0 & 0.93 & 0 & 0 & 0 \\
\hline attitude4 & 0 & 0 & 0 & 0.93 & 0 & 0 & 0 \\
\hline compatibility 1 & 0 & 0 & 0 & 0 & 0.94 & 0 & 0 \\
\hline compatibility2 & 0 & 0 & 0 & 0 & 0.93 & 0 & 0 \\
\hline compatibility 3 & 0 & 0 & 0 & 0 & 0.89 & 0 & 0 \\
\hline easeofuse1 & 0 & 0.92 & 0 & 0 & 0 & 0 & 0 \\
\hline easeofuse 2 & 0 & 0.92 & 0 & 0 & 0 & 0 & 0 \\
\hline easeofuse 3 & 0 & 0.86 & 0 & 0 & 0 & 0 & 0 \\
\hline easeofuse 4 & 0 & 0.96 & 0 & 0 & 0 & 0 & 0 \\
\hline easeofuse 5 & 0 & 0.91 & 0 & 0 & 0 & 0 & 0 \\
\hline futureuse1 & 0 & 0 & 0 & 0 & 0 & 0.93 & 0 \\
\hline futureuse 2 & 0 & 0 & 0 & 0 & 0 & 0.96 & 0 \\
\hline futureuse 3 & 0 & 0 & 0 & 0 & 0 & 0.92 & 0 \\
\hline socialstatus1 & 0 & 0 & 0 & 0 & 0 & 0 & 0.96 \\
\hline socialstatus2 & 0 & 0 & 0 & 0 & 0 & 0 & 0.92 \\
\hline socialstatus3 & 0 & 0 & 0 & 0 & 0 & 0 & 0.89 \\
\hline ICTsupport1 & 0.84 & 0 & 0 & 0 & 0 & 0 & 0 \\
\hline ICTsupport2 & 0.92 & 0 & 0 & 0 & 0 & 0 & 0 \\
\hline ICTsupport3 & 0.95 & 0 & 0 & 0 & 0 & 0 & 0 \\
\hline useful1 & 0 & 0 & 0.94 & 0 & 0 & 0 & 0 \\
\hline useful2 & 0 & 0 & 0.95 & 0 & 0 & 0 & 0 \\
\hline useful3 & 0 & 0 & 0.94 & 0 & 0 & 0 & 0 \\
\hline useful4 & 0 & 0 & 0.95 & 0 & 0 & 0 & 0 \\
\hline useful5 & 0 & 0 & 0.87 & 0 & 0 & 0 & 0 \\
\hline useful6 & 0 & 0 & 0.92 & 0 & 0 & 0 & 0 \\
\hline
\end{tabular}

Legend: $\mathrm{CW}=$ Compatibility with work; $\mathrm{SS}=$ Social status; $\mathrm{PEU}=$ perceived ease of use; $\mathrm{PU}=$ perceived usefulness; ATU $=$ Attitude to use; INTU $=$ Intention to use; FOAU $=$ Frequency of actual use

Note: Age; PEST $=$ Previous experience with similar technology; and ICTS = ICT Support were not included in this factor loadings table because these are single items which always have a factor loading of 1 .

Table 5 Factor loadings for construct items (Source: this research)

We also checked for common method bias in the measurement model which is the variance attributable to the measurement method, rather than to the measures that represent the constructs of interest in a study (Podsakoff et al. 2003). Common variance bias is a major systematic contributor to measurement error in survey research (Bagozzi \& Yi 1991). To test for the extent of bias caused by common methods variance (CMV), Harman's single factor test was conducted using an exploratory factor analysis in 
IBM SPSS version 19 (Podsakoff et al. 2003). It is argued that if there is a detrimental level of common method bias, '(a) a single factor will emerge from exploratory factor analysis (unrotated) or (b) one general factor will account for the majority of the covariance among the measures' (Podsakoff et al. 2003, p. 889). As more than one factor emerged from an exploratory factor analysis to explain the variance in our analysis, we can infer that common methods bias in this case is not high. Following the approach of Podsakoff et al. (2003), Saraf, Langdon and Gosain (2007) and Siponen and Vance (2010), a second test in PLS examined a control for the effects of an unmeasured latent methods factor in our research model (Podsakoff et al. 2003). In this analysis, of the 27 paths from methods factor to singleindicator constructs, only six were significant-indicating a relatively small amount of CMV. Hence, common methods bias has been shown to have minimal effect and is not considered to be a concern in this study.

\section{Assessment of structural model and goodness of fit - university staff adoption of iPads}

Figure 2 shows the hypothesised relationships in the PLS structural model, beta scores and the statistical significance of each hypothesised relationship and the amount of variance (R Square) explained in individual variables in the structural model.

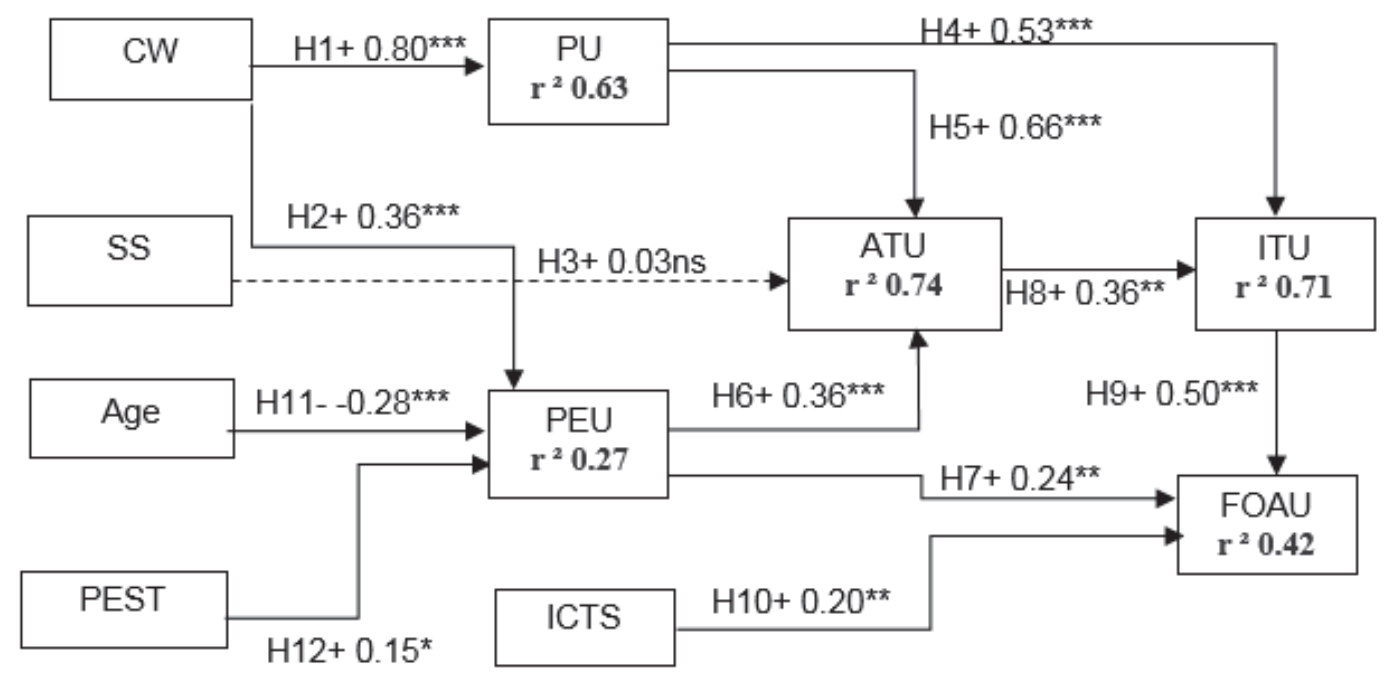

Legend CW = Compatibility with work; SS = Social status; Age; PU = perceived usefulness; $\mathrm{PEU}=$ perceived ease of use; $\mathrm{ATU}=$ Attitude to use; ITU = Intention to use; FOAU = Frequency of actual use; Age; PEST = Previous experience with similar technology; ICTS = ICT Support;

Figure 2 Final research model - University Staff adoption of iPads [Source: this research]

An overall goodness-of-fit index for the research model cannot be reported because the objective of PLS is prediction versus fit. While PLS does not provide an index that is a global validation of a research model such as covariance based SEM, $\mathrm{x} 2$ and related model fit indicators, a goodness of fit index can be calculated for a PLS model. Goodness of Fit $(\mathrm{GoF})$ represents an operational solution for validating the PLS model globally (Guenzi, Georges \& Pardo 2009). GoF is determined by calculating the geometric mean of the average communality and average R2 (Tenenhaus et al. 2005). By taking the square root of the product of the variance extracted of all constructs with multiple indicators and the 
average R2 value of the endogenous constructs, we can calculate a fit measure ranging between 0 and 1. According to the categorization by Fliess and Cohen (1973) and using .50 as a cut-off value for communality (Fornell \& Larcker 1981), the GoF criteria for small, medium and large effect sizes are $.10, .25$, and .36 respectively. The blindfolding approach proposed by Wold (1985) was used to calculate the cv-communality and cv-redundancy indexes. The cv communality index (H2) measures the quality of the measurement model; while the cv redundancy index (F2) measures the quality of the structural model. The mean of the cv communality indexes can be used to measure the global quality of the measurement model if they are positive for all blocks of variables. The global quality of the structural model can be measured by the mean of the cv-redundancy indexes related to the endogenous blocks if they are all positive (Guenzi, Georges \& Pardo 2009).

Table 6 shows that an overall large effect size is evident in the research model with GoF index of 0.55. The mean cv-communality index $(\mathrm{H} 2)$ of 0.68 indicates a large effect size for the measurement model and the mean cv-redundancy index (F2) of 0.44 indicates medium effect size for structural model.

\begin{tabular}{crrr}
\hline Construct & R2 & cv- communality & cv-redundancy \\
\hline Age & NA & NA & NA \\
ICTS & NA & 0.54 & NA \\
PEU & 0.27 & 0.73 & 0.21 \\
PU & 0.63 & 0.80 & 0.52 \\
PEST & NA & NA & NA \\
FOAU & 0.42 & NA & 0.30 \\
ATU & 0.74 & 0.71 & 0.59 \\
CW & NA & 0.65 & 0.59 \\
ITU & 0.71 & 0.69 & NA \\
SS & NA & 0.64 & NA \\
& Ave R2 -0.55 & Ave CV-Communality 0.68 & Ave CV-Redundancy 0.44 \\
& Goodness of Fit Index (GoF) 0.55 & F2 Index - \\
\hline
\end{tabular}

Legend CW = Compatibility with work; SS = Social status; PEU = perceived ease of use; PU = perceived usefulness; ATU = Attitude to use; INTU = Intention to use; FOAU = Frequency of actual use; Age; PEST = Previous experience with similar technology; ICTS = ICT Support;

Table 6 Global fit indexes for PLS measurement model and structural model (Source: this research)

\section{DISCUSSION OF KEY FINDINGS}

In this section the key findings of this study in relation to each of the twelve hypothesized relationships tested in the research model are discussed. Table 6 summarises the results of the hypothesis testing. The T Value Statistics column indicates the level of significance at which hypotheses have been supported. All hypotheses except hypothesis H3 are accepted at the 0.05 level of significance. 
T Values

Significance

12 Hypotheses tested in research model

Levels

HI: Compatibility of an iPad with staff work is positively associated with the perceived usefulness of an iPad (supported)

$3.68 * * *$

H2: Compatibility of an iPad with staff work is positively associated with the perceived ease of use of an iPad (supported)

$19.66 * * *$

H3: The social status of using an iPad has a positive association with the attitude to using an iPad (not supported)

$0.46 \mathrm{~ns}$

H4: Perceived usefulness of an iPad has a positive association with the intention

to use an iPad (supported)

$3.98 * * *$

H5: Perceived usefulness of an $\mathrm{iPad} /$ tablet has a positive association on the attitude towards using an iPad (supported)

H6: Perceived ease of use of an iPad has a positive association with the attitude towards using an iPad (supported)

H7: Perceived ease of use of an iPad has a positive association with the frequency of actual use of an iPad (supported)

H8: Attitude towards using an iPad has a positive association with the intention to use an iPad (supported)

H9: Intention to use an iPad has a positive association with the frequency of actual use of an iPad (supported)

H10: ICT support has positive association with the frequency of actual use of an iPad (supported)

H11: Users with previous experience of using a similar technology such as an

iPhone or smartphone will rate the perceived ease of use of an iPad higher than users with no previous experience of using a similar technology such as an iPhone or smartphone (supported)

H12: Age is negatively associated with the perceived ease of use of an iPad (supported)

Legend CW = Compatibility with work; SS = Social status; PEU = perceived ease of use; PU = perceived usefulness; ATU = Attitude to use; INTU = Intention to use; FOAU = Frequency of actual use; Age; PEST = Previous experience with similar technology; ICTS = ICT Support;

Table 6 Summary of Results of Hypothesis Testing (Source: this research)

H1: Compatibility of an iPad with staff work is positively associated with the perceived usefulness of an $\mathrm{iPad}-$ supported with a beta score of 0.80 and a strong level of significance.

H2: Compatibility of an iPad with staff work is positively associated with the perceived ease of use of an $\mathrm{iPad}$ - supported with a beta score of 0.35 and a strong level of significance.

The findings regarding $\mathrm{H} 1$ and $\mathrm{H} 2$ shows that university staff in general perceived an iPad to be highly compatible with their work and, therefore, strongly influenced their perception of the usefulness of an iPad; and, to a lesser extent, their perception of ease of use of an iPad. These findings in relation to $\mathrm{H} 1$ and $\mathrm{H} 2$ are consistent with the findings of a number of previous studies which found support for the relationship between compatibility and perceived usefulness and perceived ease of use (Chau \& $\mathrm{Hu}$ 2001; Lai \& Chang 2011; Oh, Ahn \& Kim 2003). Indeed, the compatibility of a technological innovation such as an iPad is considered to be an antecedent of its perceived usefulness and perceived ease of use. 
H3: The social status of using an iPad has a positive association with the attitude to using an iPad-not supported with a beta score of 0.03 and not significant.

Hypothesis H3 was based on the assumption that the social status associated with using a new technology innovation such as an iPad may be an influencing factor in technology adoption (Karahanna, Straub \& Chervany 1999; Moore \& Benbasat 1991). Hypothesis H3 was not supported with a beta score of 0.03 , which was not significant at the 0.05 level. Furthermore, an analysis of the survey responses for the three social status survey items showed that 65-75 percent of the survey responses displayed either a neutral or negative stance to the suggestion that any social status is bestowed by ownership of one of these devices, or that enhanced status is an influencing factor to adoption. Hence, the finding in this study regarding $\mathrm{H} 3$ is contrary to previous studies which found the social status gained from using a new technological innovation was positively associated with the attitude to using a new technological innovation (in this study an iPad) (Choi et al. 2003; Lu \& Viehland 2008). However, this finding is supported by other studies which have found that social status or image inferred with the adoption and use of a technological innovation (in this study an iPad) to be a weak predictor of a user's attitude to adoption of a new technology (Karahanna, Straub \& Chervany 1999; Moore \& Benbasat 1991).

H4: Perceived usefulness of an iPad has a positive association with the intention to use an iPadsupported with a beta score of 0.66 and a strong level of significance.

H5: Perceived usefulness of an iPad/tablet has a positive association on the attitude towards using an iPad-supported with a beta score of 0.53 and a strong level of significance.

The findings show that there is strong support for $\mathrm{H} 4$ and $\mathrm{H} 5$ and the perceived usefulness of a technological innovation such as an iPad is positively associated with university staff's attitude and intent to using an iPad. Hence, the perceived usefulness of an iPad in university staff's work would appear to a key driver and determinant of the adoption and use of an iPad by university staff. These findings are similar to previous studies which found that perceived usefulness was positively associated with attitude towards adoption and the intention to use a technological innovation that is mobile and/or internet enabled (Chong et al. 2010; Lee, Cheung \& Chen 2005; Tan et al. 2012).

H6: Perceived ease of use of an iPad has a positive association with the attitude towards using an iPadsupported with a beta score of 0.24 and a strong level of significance.

H7: Perceived ease of use of an iPad has a positive association with the frequency of actual use of an iPad-supported with a beta score of 0.36 and a strong level of significance.

The findings regarding $\mathrm{H} 6$ and $\mathrm{H} 7$ show perceived ease of use is moderately and positively associated with the attitude of university staff to using an iPad and the frequency of their actual use of an iPad in their work. These findings regarding $\mathrm{H} 6$ and $\mathrm{H} 7$ are consistent with previous studies that found perceived ease of use leads to an increased positive attitude to use of a technological innovation (in this study an iPad) and increased frequency of actual use (Davis 1989; Tan et al. 2012).

H8: Attitude towards using an iPad has a positive association with the intention to use an iPadsupported with a beta score of 0.36 and a strong level of significance.

H9: Intention to use an iPad has a positive association with the frequency of actual use of an iPadsupported with a beta score of 0.50 and a strong level of significance.

The findings show that there is moderate to strong support for the positive relationship between university staff attitude to using an iPad and their intention to use an iPad and their actual use of an iPad. Hence, the findings show that the attitude of university staff towards a technological innovation such as an iPad translates into intent to use and then actual use of an iPad. These findings are similar to a number of previous studies which found the attitude towards a technological innovation positively influenced the intention to use and the actual use of a technological innovation (Karahanna, Straub \& 
Chervany 1999; Lapczynski \& Calloway 2006; Lu \& Viehland 2008; Tan et al. 2012). Indeed, three of these previous studies examined these relationships in a similar context of mobile computing and mobile learning (Lapczynski \& Calloway 2006; Lu \& Viehland 2008; Tan et al. 2012).

H10: ICT support has a positive association with the frequency of actual use of an iPad-supported, but with a negative beta score of $\mathbf{- 0 . 2 0}$ and a strong level of significance.

The findings show that ICT Support has a moderate association with the frequency of actual use of an iPad. However, the beta score for the hypothesised relationship is negative-which is the reverse of the positive relationship that was predicted. ICT support was found to have a negative impact on the actual use of an iPad by university staff, with most respondents disagreeing that there was adequate ICT support. This finding confers with previous studies using an extended TAM that also found technology support at the organisation level was a critical factor for user adoption and use of a technology innovation (Horan et al. 2004; Schaper \& Pervan 2007). Moreover, this finding can be explained in the context of this study because, currently, the university does not provide any formal, dedicated support for mobile devices such as iPads, Android tablets and Windows tablets. For iPads (and other touch mobile devices) there is lack of enterprise wide solutions for managing the use of apps by university staff in their work. An ICT services support model for these mobile devices is challenging and, potentially, has significant human resourcing implications for University ICT support services.

H11: Users with previous experience of using a similar technology such as an iPhone or smartphone will rate the perceived ease of use of an iPad higher than users with no previous experience of using a similar technology such as an iPhone or smartphone-supported with a beta score of 0.15 and a moderate level of significance.

Previous experience in using a similar technology such as an iPhone/smartphone (nominal variable) was converted to a binary variable. This allowed us to compare the difference between university staff with previous experience in using similar technology such as an iPhone or smartphone against those with no previous experience in percentage terms for the beta score of the hypothesised relationship. The finding regarding hypothesis H11 shows that university staff with previous experience in using a similar technology such as an iPhone or smartphone rated perceived ease of use of an iPad 22 percent higher than university staff with no previous experience in using a similar technology such as an iPhone or smartphone. This finding provides support for a number of previous studies that identified that previous experience in using a similar technology (in this study, iPhones and smart phones based on similar interfaces and operating systems) will result in users rating the perceived ease of use of a technology innovation (in this study an iPad) much higher (Lu \& Viehland 2008; Tan et al. 2012).

H12: Age is negatively associated with the perceived ease of use of an iPad-supported with a negative beta score of $\mathbf{- 0 . 2 8}$ and a strong level of significance.

The finding regarding the result of H12 hypothesis test shows that age is moderately negatively associated with the perceived ease of use of an iPad. In other words, university staff in the older age categories of 46-55 years and over 55 years rated perceived ease of use of iPads lower than university staff in the younger age categories. This finding is consistent with the findings of a number of previous studies which found that age is a barrier to the adoption of new technological innovations (Goldin \& Katz 2008; Reisdorf 2011; Wang, Dou \& Zhou 2008).

\section{CONCLUSIONS AND IMPLICATIONS}

There has been little previous empirical research conducted on the adoption of iPads by university staff. This study provides support for a validated model for the adoption of iPads by university staff using an extended variant of TAM contextualised to the higher education environment. 
Clearly our findings show there is a strong level of positive adoption of iPads across the academic and professional university staff workforce in one regional university; and anecdotal reports indicate a similar worldwide trend with potential for universities to leverage the affordances and ubiquity of these devices for educational and/or other work purposes.

Whilst the findings point to a strong perception of iPad compatibility with the work undertaken by university professional and academic staff, there are a number of strategic imperatives that universities need to consider as a result. As mobile devices such as iPads become mainstream in the work of university staff, ICT departments will need to deliver more appropriate user-centred ICT support models. In particular, our findings suggest that older staff and staff with no or little previous experience of using a similar technology such as an iPhone or smartphone will require more end user support from ICT Services departments when using mobile devices such as iPads.

As with all research there are some limitations in this study. The number of useable responses was not sufficient to use covariance based SEM. Future work could extend this research to other universities and other industry sectors and provide further validation of the extended TAM for evaluating staff adoption of both iPads and Android tablets in the workplace. Additional work is also required to develop models which can longitudinally evaluate the effective ongoing use of mobile devices in general by university staff beyond the initial adoption phase of a technological innovation such as an iPad.

\section{ACKNOWLEDGMENTS}

The authors express their gratitude to our USQ colleagues Michael Gardiner, Dr Mustafa Ally, Associate Professor Jane Summers and Justine Fritisch for their assistance in pre-testing the face validity of our survey instrument. The financial and in-kind support received from the Faculty of Business and Law and Associate Professor Jane Summers (Associate Dean Learning and Teaching) is also gratefully acknowledged. Lastly, the generous time-release for Mr Adrian Stagg granted by the Australian Digital Futures Institute at USQ is acknowledged, as without it the data collection for this research would have been more difficult.

\section{REFERENCES}

Ajzen, I \& Fishbein, M (1980), Understanding Attitudes and Predicting Social Behaviour, PrenticeHall, Englewood Cliffs, NJ.

Bagozzi, RP \& Yi, Y (1991), 'Multitrait-Multimethod Matrices in Consumer Research, Journal of Consumer Research, vol. 17, no. 4, pp. 426-39.

Barclay, D, Thompson, R \& Higgins, C (1995), 'The Partial Least Squares (PLS) Approach to Causal Modeling: Personal Computer Adoption and Use: An Illustration', Technology Studies, vol. 2, no. 2, pp. 285-309.

Becker, B (2011), 'The e-Book Apocalypse: A Survivor's Guide', Behavioral and Social Sciences Librarian, vol. 30, no. 3, pp. 181-4.

Carmines, E \& Zeller, R (1979), Reliability and Validity Assessment, Sage Publications, Beverly Hills.

Caudill, JG (2007), 'The Growth of m-Learning and the Growth of Mobile Computing: Parallel developments', The International Review of Research in Open and Distance Learning, vol. 8, no. 2, viewed 07 April 2014.

Chau, PYK \& Hu, PJH (2001), 'Information technology acceptance by individual professionals: a model comparison approach', Decision Sciences, vol. 32, no. 4, pp. 699-719.

Chin, W (1998), 'The Partial Least Squares Approach to Structural Equation Modeling', in G Marcoulides (ed.), Modern Methods for Business Research, Psychology Press, London, pp. 295 $-336$. 
Choi, H, Choi, M, Kim, J \& Yu, H (2003), 'An empirical study on the adoption of information appliances with a focus on interactive TV', Telematics and Informatics, vol. 20, pp. 161-83.

Chong, AYL, Ooi, KB, Darmawan, N \& Lee, VH (2010), 'Determinants of 3G adoption in Malaysia: A structural analysis', Journal of Computer Information Systems, vol. 51, no. 2, pp. 71-80.

Costello, S (2014), 'What Are iPad Sales All Time?', About.com iPhone / iPod, <http://ipod.about.com/od/ipadmodelsandterms/f/ipad-sales-to-date.htm>

Cross, K (2010), September 11, 'iPad Replaces Uni Textbooks at University of Adelaide Science Faculty', The Advertiser, viewed 27th August 2012, <http://www.adelaidenow.com.au/news/ipad-replaces-uni-textbooks-at-university-of-adelaidescience-faculty/story-fn5jhv6y-1225918213032>

Davis, F (1989), 'Perceived Usefulness, Perceived Ease of Use, and User Acceptance of Information Technology', MIS Quarterly, vol. 13, no. 3, pp. 319-39.

Davis, F, Bagozzi, R \& Warshwa, P (1989), 'User Acceptance of Computer Technology: A Comparison of Two Theoretical Models', Management Science, vol. 35, no. 8, pp. 982-1003.

Eikebrokk, TR \& Olsen, DH (2007), 'An empirical investigation of competency factors affecting ebusiness success in European SMEs', Information \& Management, vol. 44, no. 4, pp. 364-83.

Fleiss, J \& Cohen, J (1973), 'The equivalence of weighted kappa and the intraclass correlation coefficient as measures of reliability', Educational and Psychological Measurement, vol. 33, pp. 613-9.

Fornell, C \& Larcker, D (1981), 'Evaluating Structural Equation Models with Unobservable Variables and Measurement Error', Journal of Marketing Research, vol. 18, no. 1, pp. 39-50.

Gerpott, T, Thomas, S \& Weichert, M (2013), 'Personal Characteristics and Mobile Internet Use Intensity of Consumers with Computer-Centric Communication Devices: An Exploratory Empirical Study of iPad and Laptop Users in Germany', Telematics and Informatics, vol. 30, no. 2, pp. 87-99.

Ghapanchi, AH \& Aurum, A (2012a), 'Competency rallying in electronic markets: implications for open source project success', Electronic Markets, vol. 22, no. 2, pp. 117-27.

Ghapanchi, AH \& Aurum, A (2012b), 'The impact of project capabilities on project performance: Case of open source software projects', International Journal of Project Management, vol. 30, no. 4, pp. 407-17.

Ghapanchi, AH \& Aurum, A (2011), 'Measuring the Effectiveness of the Defect-Fixing Process in Open Source Software Projects', in: Proceedings of the 44th Hawaii International Conference on Systems Sciences (HICSS) pp. 1-11.

Goldin, C \& Katz, L (2008), The Race between Education and Technology, Belknap, Cambridge.

Guenzi, P, Georges, L \& Pardo, C (2009), 'The Impact of Strategic Account Managers' Behaviors on Relational Outcomes: An Empirical Study', Industrial Marketing Management, vol. 38, no. 3, pp. 300-11.

Guiltinan, J (1999), 'Launch strategy, launch tactics, and demand outcomes', Journal of Product Innovation Management, vol. 16, no. 6, pp. 509-29.

Hair, JF, Sarstedt, M, Ringle, CM \& Mena, JA (2012), 'An assessment of the use of partial least squares structural equation modeling in marketing research', Journal of Academic Marketing Science, vol. 40, no. 3, pp. 414-33.

Henseler, J, Ringle, CM \& Sinkovics, RR (2009), 'The use of partial least squares path modeling in international marketing', in Advances in international marketing, Emerald, Bingley, vol. 20, pp. 277-319. 
Holak, S \& Lehmann, D (1990), 'Purchase intentions and the dimensions of innovation: an exploratory model', Journal of Product Innovation Management, vol. 7, no. 1, pp. 59-73.

Hoover, D \& Valencia, J (2011), 'iPads in the Classroom: Use, Learning Outcomes, and the Future. Presentation', in Proceedings of the 2011 EDUCAUSE Annual Conference Philadelphia, PA, <http://www.educause.edu/sites/default/files/library/presentations/E11/SESS081/iPads\%2Bin $\%$ 2Bthe\%2BClassroom.pdf $>$.

Horan, TA, Tulu, B, Hilton, B \& Burton, J (2004), 'Use of Online Systems in Clinical Medical Assessments: An Analysis of Physician Acceptance of Online Disability Evaluation Systems ', in Proceedings of the 37th Hawaii International Conference on System Sciences IEEE, Hawaii.

Igbaria, M, Zinatelli, N, Cragg, P \& M, CAL (2007), 'Personal Computing Acceptance Factors in Small Firms: A Structural Equation Model', MIS Quarterly, vol. 21, no. 3, pp. 279-305.

Jackson, C, Chow, S \& Leitch, R (1997), 'Toward an understanding of the behavioral intention to use an information system', Decision Sciences, vol. 28, no. 2, pp. 357-89.

Kagaari, J, Munene, J \& Ntayi, J (2010), 'Performance Management Practices, Information and Communication Technology (ICT) Adoption and Managed Performance', Quality Assurance in Education, vol. 18, no. 2, pp. 106-25.

Karahanna, E, Straub, DW \& Chervany, ML (1999), 'Information technology adoption across time: A cross-sectional comparison of pre-adoption and post-adoption beliefs', MIS Quarterly, vol. 23, no. 2, pp. 183-213.

Kelly, J \& Schrape, J (2010), '100 Days with an iPad: Lessons Learnt and Apps Acquired', in proceedings of the Curriculum, Technology and Transformation for an Unknown Future, $\mathrm{CH}$ Steel, et al. (eds.), Ascilite, Sydney, pp. 484-6.

Knight, S \& Burn, J (2011), 'Introducing the OTAM: Exploring Users' End Perceptions of Their OnGoing Interaction with Adopted Technologies', Australasian Journal of Information Systems, vol. 17, no. 1, pp. 5-41.

Kotler, P (2003), Marketing Management: Analysis, Planning, Implementation, and Control, 11th edn, Prentice Hall, Englewood Cliffs, NJ.

Kukulska-Hume, A (2012), 'How Should the Higher Education Workforce Adapt to the Advancements in Technology for Teaching and Learning?', Internet and Higher Education, vol. 15, no. 4, pp. 247-54.

Lai, J-Y \& Chang, C-Y (2011), 'User attitudes toward dedicated e-book readers for reading: The effects of convenience, compatibility and media richness', Online Information Review, vol. 35, no. 4, pp. 558-80.

Lapczynski, P \& Calloway, L (2006), 'A Scheme of Technology Acceptance for Mobile Computing', in M Khosrow-Pour (ed.), Emerging Trends and Challenges in Information Technology, Idea Group Incorporated, vol. 1.

Lee, MKO, Cheung, CMK \& Chen, Z (2005), 'Acceptance of Internet-based learning medium: The role of extrinsic and intrinsic motivation', Information and Management, vol. 42, no. 8, pp. 1095104.

Lee, Y, Kozar, K \& Larsen, K (2003), 'The Technology Acceptance Model: Past, Present, and Future', Communications of the Association for Information Systems, vol. 12, no. 50, pp. 752-80.

Liu, I, Chen, M, Sun, Y, Wible, D \& Kuo, C (2010), 'Extending the TAM Model to Explore the Factors that Affect Intention to use an Online Learning Community', Computers \& Education, vol. 54, no. 2 , pp. $600-10$. 
Lu, X \& Viehland, D (2008), 'Factors influencing the adoption of mobile learning', in proceedings of the Australasian Conference on Information Systems Univerity of Canterbury, Christchurch, New Zealand, <http://aisel.aisnet.org/acis2008/56>.

Maddux, C \& Johnson, D (2010), 'Global Trends and Issues in Information Technology in Education', Computers in Schools, vol. 27, no. 3/4, pp. 145-54.

Malhotra, Y \& Galleta, D (1999), 'Extending the Technology Acceptance Model to Account for Social Influence: Theoretical Bases and Empirical Validation', in proceedings of the 32nd Hawaii International Conference on System Sciences IEEE, Hawaii.

Matthieson, K (1991), 'Predicting User Intentions: Comparing the Technology Acceptance Model with the Theory of Planned Behaviour', Information Systems Research, vol. 2, no. 3, pp. 173-91.

McFarland, D \& Hamilton, D (2006), 'Adding Contextual Specificity to the Technology Acceptance Model', Computers in Human Behaviour, vol. 22, no. 3, pp. 427-47.

Moore, G \& Benbasat, I (1991), 'Development of an Instrument to Measure the Perceptions of Adopting an Information Technology Innovation', Information Systems Research, vol. 2, no. 3, pp. 192222.

Moran, M, Hawkes, M \& El Gayar, O (2010), 'Tablet Personal Computer Integration in Higher Education: Applying the Unified Theory of Acceptance and Use Technology Model to Understand Supporting Factors', Journal of Education Computing Research, vol. 42, no. 1, pp. 79-101.

Murphy, A, Farley, H, Lane, M, Hafeez- Baig, A \& Carter, B (2013), 'Mobile learning anytime, anywhere: What are our students doing? (ACPHIS Kit Dampney Best paper award for an educational issue)', in Proceedings of the 24th Australasian Conference of Information Systems RMIT, Melbourne, Australia, <http://mo.bf.rmit.edu.au/acis2013/306.pdf>.

Nair, I \& Das, V (2011), 'Analysis of Recent Studies Undertaken for Assessing Acceptance of Technology Among Teachers using TAM', International Journal of Computer Applications, vol. 32, no. 8, pp. 38-46.

Nunnally, J (1979), Psychometric Theory, McGraw-Hill, New York.

Oh, S, Ahn, J \& Kim, B (2003), 'Adoption of broadband internet in Korea: the role of experience in building attitudes', Journal of Information Technology Theory and Application, vol. 18, no. 4, pp. 267-80.

Oldfield, J \& Cochrane, T (2011), 'Equipping Lecturers for the iRevolution', in proceedings of the ASCILITE Conference, G Williams, et al. (eds.), Hobart, pp. 919-29.

Ong, J (2011), Apple Maintains Dominance of Global Market with 58\% Share in Q4 2011, viewed 10th October

<http://www.appleinsider.com/articles/12/01/26/apple_maintains_dominance_of_global_tablet _market_with_58_share_in_q4_2011.html >

Park, S (2009), 'An Analysis of the Technology Acceptance Model in Understanding University Students' Behavioural Intention to use e-Learning', Educational Technology and Society, vol. 12, no. 3, pp. 150-62.

Park, S, Nam, M \& Cha, S (2011), 'University Students' Behavioural Intention to Use Mobile Learning: Evaluating the Technology Acceptance Model', British Journal of Educational Technology, vol. 43, no. 4, pp. 1-13.

Pepperdine University 2012, iPad Research Study, Pepperdine University, viewed 10th October 2012, <https://community.pepperdine.edu/it/tools/ipad/research/default.htm>. 
Podsakoff, P, MacKenzie, S, Lee, J \& Podsakoff, N (2003), 'Common Method Biases in Behavioral Research: A Critical Review of the Literature and Recommended Remedies', Journal of Applied Psychology, vol. 88, no. 5, pp. 879-903.

Read, W, Robertson, N \& McQuilken, L (2011), 'A Novel Romance: The Technology Acceptance Model with Emotional Attachment', Australasian Marketing Journal, vol. 19, no. 4, pp. 223-9.

Reisdorf, B (2011), 'Non-adoption of the Internet in Great Britain and Sweden', Information, Communication and Society, vol. 14, no. 3, pp. 400-20.

Ringle, CM, Wende, S \& Will, A (2005), SmartPLS Release: 2.0 (beta), University of Hamburg, viewed 20th September 2012, <http://www.smartpls.de >.

Saraf, N, Langdon, C \& Gosain, S (2007), 'IS Application Capabilities and Relational Value in InterFirm Partnerships', Information Systems Research, vol. 18, no. 3, pp. 320-39.

Schaper, L \& Pervan, G (2007), 'An investigation of factors affecting technology acceptance and use decisions by Australian allied health therapists ', in Proceedings of the 40th Hawaii International Conference on System Sciences Hawaii, <http://www.computer.org/csdl/proceedings/hicss/2007/2755/00/27550141c.pdf>.

Shen, J (2010), 'The eBook Lifestyle: An Academic Library Perspective', The Reference Librarian, vol. 52, no. 1-2, pp. 181-9.

Shih, C \& Venkatesh, A (2004), 'Beyond Adoption: Development and Application of a Use-Diffusion Model', Journal of Marketing Research, vol. 68, no. 1, pp. 59-72.

Shurtz, S, Halling, T \& McKay, B (2011), 'Assessing User Preferences to Circulate iPads in an Academic Medical Library', Journal of Electronic Resources in Medical Libraries, vol. 8, no. 4, pp. 311-24.

Siponen, M \& Vance, A (2010), 'Neutralisation: New insights into the problem of employee information systems security policy violations', MIS Quarterly, vol. 34, no. 3, pp. 487-502.

Straub, D, Keil, M \& Brenner, W (1997), 'Testing the Technology Acceptance Model Across Cultures: A Three Country Study', Information and Management, vol. 33, no. 1, pp. 1-11.

Straub, D, Boudreau, M \& Gefen, D (2004), 'Validation Guidelines for IS Positivist Research', Communications of the Association for Information Systems, vol. 13, no. 24, pp. 380-427.

Tan, GWH, Sim, JJ, Ooi, KB \& Phusavat, K (2012), 'Determinants of Mobile learning adoption: An empirical analysis', Journal of Computer Information Systems, vol. 52, no. 3, pp. 81-92.

Taylor, S \& Todd, PA (1995), 'Understanding information technology usage: a test of competing models', Information Systems Research, vol. 6, no. 2, pp. 144-76.

Tenenhaus, M, Vinzi, V, Chatelin, Y-M \& Lauro, C (2005), 'PLS Path Modelling', Computational Statistics \& Data Analysis, vol. 48, no. 1, pp. 159-205.

Thompson, R, Higgins, C \& Howell, J (1991), 'Personal Computing: Toward a Conceptual Model of Utilization', MIS Quarterly, vol. 15, no. 1, pp. 124-43.

Tornatzky, L \& Klein, K (1982), 'Innovation characteristics and innovation adoption-implementation: a meta-analysis of findings', IEEE Transactions on Engineering Management, vol. 29, no. 1, pp. $28-45$.

Wang, G, Dou, W \& Zhou, N (2008), 'Consumption Attitudes and Adoption of New Consumer Products: A Contingency Approach', European Journal of Marketing, vol. 42, no. 1/2.

Wiebrands, M (2012), 'The Coming Paradigm Shift in Computing Interfaces and How Academic Libraries Need to Adapt', in proceedings of the IATUL 2009 Conference Purdue University, <http://docs.lib.purdue.edu/iatul/2012/papers/9>. 
Wold, H (1985), 'Systems Analysis by Partial Least Squares', in P Nijkamp, et al. (eds), Measuring the Unmeasurable, Martinus Nijhoff, Boston, MA.

Wu, C, Kuo, Y \& Wu, S (2013), 'Investigating the Antecedents of University Students' Behavioral Intention to Use iPad for Learning ', International Journal of e-Education, e-Business, eManagement and e-Learning, vol. 3, no. 6, pp. 468-71. 


\section{APPENDIX A - UNIVERSITY STAFF ADOPTION OF IPADS MODEL - SURVEY} INSTRUMENT

\begin{tabular}{|c|c|}
\hline Construct & Survey items \\
\hline \multicolumn{2}{|c|}{ Compatibility with work (CW) } \\
\hline Compatibility 1 & An iPad/Tablet is compatible with most aspects of my work. \\
\hline Compatibility2 & An iPad/Tablet fits well with the way I like to work. \\
\hline Compatibility3 & An iPad/Tablet is compatible with other systems I use. \\
\hline \multicolumn{2}{|c|}{ Social Status (SS) } \\
\hline Social status 1 & $\begin{array}{l}\text { People in my organisation who use an iPad/Tablet have more prestige than those } \\
\text { who do not. }\end{array}$ \\
\hline Social status2 & People in my organisation who use an iPad/Tablet have a high profile. \\
\hline Social status3 & Having an iPad/Tablet is a status symbol in my organisation. \\
\hline \multicolumn{2}{|c|}{ ICT Support (ICTS) } \\
\hline ICT Support1 & Guidance was available to me in selection of suitable iPad/Tablet apps \\
\hline ICT Support2 & Specialized instruction on the use of an $\mathrm{iPad} / \mathrm{Tablet}$ was available to me. \\
\hline ICT Support3 & $\begin{array}{l}\text { A specific person (or group) is available for assistance with iPad/Tablet } \\
\text { difficulties. }\end{array}$ \\
\hline \multicolumn{2}{|c|}{ Perceived usefulness (PU) } \\
\hline PU1 & An iPad/Tablet in my job enables me to accomplish some tasks more quickly. \\
\hline PU2 & An iPad/Tablet helps improve my job performance. \\
\hline PU3 & An iPad/Tablet in my job increases my productivity. \\
\hline PU4 & An iPad/Tablet enhances my effectiveness on the job. \\
\hline PU5 & An iPad/Tablet makes it easier to do some aspects of my job. \\
\hline PU6 & An iPad/Tablet is useful in my job. \\
\hline \multicolumn{2}{|c|}{ Perceived ease of use (PEU) } \\
\hline PEU1 & Learning to use an iPad/Tablet is easy for me. \\
\hline PEU2 & It is easy to make an $\mathrm{Pad} / \mathrm{Tablet}$ do what I want it to. \\
\hline PEU3 & It is clear and understandable how I interact with iPad/Tablet through touch. \\
\hline PEU4 & It has been easy for me to become skillful at using an $\mathrm{iPad} / \mathrm{Tablet}$. \\
\hline PEU5 & It is easy to use an iPad/Tablet. \\
\hline \multicolumn{2}{|c|}{ Attitude to use (ATU) } \\
\hline Attitude1 & Using an iPad/Tablet is good experience. \\
\hline Attitude2 & Using an iPad/Tablet makes my work more interesting. \\
\hline Attitude3 & Using an $\mathrm{iPad} / \mathrm{Tablet}$ is a fun experience. \\
\hline Attitude4 & I like using an iPad/Tablet in my work. \\
\hline \multicolumn{2}{|c|}{ Intention to use (ITU) } \\
\hline Intention 1 & I intend to use an iPad/Tablet as a routine part of my job over the next year. \\
\hline Intention2 & I intend to use an iPad/Tablet more at every opportunity. \\
\hline Intention3 & I plan to increase my use of an iPad/Tablet over the next year. \\
\hline $\begin{array}{l}\text { Frequency of } \\
\text { actual use } \\
\text { (FOAU) }\end{array}$ & $\begin{array}{l}\text { Frequency of actual use in work; } 7 \text { point likert scale; Less than once a week } \\
\text { through to constantly using during a day }\end{array}$ \\
\hline Age & What is your age? $18-25 ; 26-35 ; 36-45 ; 46-55$, over 55 \\
\hline \multicolumn{2}{|c|}{ Previous experience using iPhone or smartphone (PEST) } \\
\hline
\end{tabular}

Table 8 Construct survey items (Source: adapted previous instruments for this research. See Table 1 for specific references for construct survey items)] 